\title{
Prevention of ventilator-associated pneumonia in adults
}

\section{Hallie C Prescott* and James M O’Brien}

\author{
Address: Department of Internal Medicine, The Ohio State University, 395 West 12th Avenue, Columbus, OH 43210, USA \\ * Corresponding author: Hallie C Prescott (hallie.prescott@osumc.edu) \\ FI000 Medicine Reports 2010, 2:15 (doi:10.3410/M2-15)
}

The electronic version of this article is the complete one and can be found at: http://fl000.com/reports/medicine/content/2/I5

\begin{abstract}
Ventilator-associated pneumonia, broadly defined as pneumonia that develops after 48 hours of intubation, is a common mechanical ventilation complication that causes significant morbidity and mortality in critically ill patients. Prevention strategies are continually evolving to decrease the impact of this serious and costly disease.
\end{abstract}

\section{Introduction and context}

Ventilator-associated pneumonia (VAP) is thought to develop from microorganisms entering the sterile lower respiratory tract by aspiration of oropharyngeal secretions containing bacteria endemic to the digestive tract or exogenous pathogens acquired from contaminated equipment or health care workers $[1,2]$. Less commonly, the lower respiratory tract may be inoculated by direct inhalation of pathogens, hematogenous spread from a remote infection, or direct extension of a contiguous infection $[1,2]$. The most common etiologic agents are Pseudomonas aeruginosa, Klebsiella pneumoniae, Escherichia coli, Acinetobacter, and Staphylococcus aureus [1]. In healthy hosts, mucociliary clearance and innate immunity protect against pneumonia [2]. However, placement of an endotracheal tube impairs mucociliary clearance and provides a direct pathway for inoculation of the lower respiratory tract while critical illness weakens the immune system, putting critically ill, ventilated patients at high risk for developing pneumonia [2].

Prevention strategies focus on decreasing bacterial colonization of the oropharynx, reducing the frequency of aspiration, maintaining the immune system, and liberating patients from the ventilator as early as possible. These strategies have improved over the past decade and decreased the burden of disease. VAP previously occurred in $9-18 \%$ of mechanically ventilated patients [3] and was associated with a $20-50 \%$ mortality rate and a 7- to 9-day increase in hospitalization [4].
Newer data suggest that VAP incidence is 2-10 per 1000 ventilator days [5]. The cost of diagnosing and treating VAP is US $\$ 5,000$ to $\$ 40,000$ per incident $[6,7]$. Routine prevention strategies are summarized in Table 1. Emerging prevention strategies to consider in selected patient populations are summarized in Table 2 .

\section{Recent advances \\ Decreasing bacterial colonization of the oropharynx}

In 2005, the Infectious Diseases Society of America and the American Thoracic Society published a comprehensive guideline for VAP prevention focusing on modifiable risk factors [1]. In 2008, the Canadian Critical Care Trials group published a similar guideline [8]. To decrease bacterial colonization of the oropharynx and endotracheal tube, these guidelines advocate using orotracheal rather than nasotracheal intubation, continuous subglottic secretion drainage, and standard infection control measures, including frequent hand washing, sterile central venous catheter placement, and isolation of resistant organisms. While continuous subglottic secretion drainage requires a special endotracheal tube that costs about US \$12 more than a standard tube, several studies have shown a significant reduction of VAP incidence with this intervention, as summarized in a recent review [9].

Decontamination of the oropharynx and digestive tract with systemic antibiotics, selective digestive decontamination, and selective oropharyngeal decontamination have all been shown to decrease bacterial colonization and VAP 
Table I. Recommended prevention strategies for ventilatorassociated pneumonia in adult intensive care units

Avoidance of intubation and reintubation if possible Orotracheal intubation over nasotracheal intubation

Continuous aspiration of subglottic secretions

Semi-recumbent positioning (head of bed elevated

30-45 degrees when possible)

Enteral feeding with post-pyloric feeding tube

Standard infection control measures

Daily sedation interruption paired with ventilator weaning protocol

Conservative transfusion policy

Sucralfate or $\mathrm{H} 2$ blockers over proton pump inhibitors for stress ulcer prophylaxis

Table 2. Ventilator-associated pneumonia prevention strategies to consider in selected patients

\section{Early tracheostomy}

Chlorhexidine mouthwash

Coated endotracheal tubes

incidence [10], but the practice remains controversial. While many studies have demonstrated decreased VAP incidence in patients treated with prophylactic antibiotics $[10]$, the guidelines recommend against their use until more data on the effect on mortality and the risk of developing resistant organisms emerge $[1,8]$. In 2009, De Smet et al. [11] published the largest randomized trial to date on selective gut decontamination. After baseline differences between the treatment arms were adjusted for, there was a significant decrease in mortality for those treated with selective gut decontamination [11]. However, concerns about the external validity of the study remain because of the low incidence of resistant organisms encountered in the study population [12].

Oral cleansing with topical antiseptics such as chlorhexidine also reduces bacterial colonization with less potential for selecting resistant organisms but is similarly controversial. The 2005 guidelines recommend against using antiseptics because of the paucity of data [1]. Many subsequent trials on chlorhexidine have been published, but the results are conflicting so the controversy persists. Several metaanalyses $[1,13]$ and clinical trials $[14,15]$ suggest a benefit of chlorehexidine in decreasing VAP, whereas others have yielded negative results [16-18]. The 2008 guidelines recommend that oral chlorhexidine be considered [8].

Since the 2008 guidelines were published, a new silvercoated endotracheal tube designed to decrease bacterial colonization and biofilm formation was introduced. The NASCENT trial, a prospective, randomized, multi-center study comparing standard and coated endotracheal tubes, showed a significant reduction in VAP $(4.8 \%$ versus $7.5 \%, P=0.03$ ) in patients treated with this coated tube. However, mechanical ventilation duration, hospital length of stay, and intensive care unit (ICU) length of stay were unchanged between the control and intervention groups [4]. A numeric increase in mortality among patients assigned to the coated tubes $(30.4 \%$ versus $26.6 \%$ for standard tubes, $P=0.11$ ) needs to be evaluated further [4]. Furthermore, the cost of a coated tube is US $\$ 90$ compared with $\$ 2$ for a routine tube, but a recent cost-effectiveness analysis concluded that silvercoated tubes would likely save money because of their ability to prevent VAP [19].

\section{Decreasing the frequency of aspiration}

Enteral nutrition predisposes patients to aspiration of gastric contents and subsequent VAP [20] but is still considered preferable to parenteral nutrition because of the many complications associated with parenteral nutrition [20,21]. The 2005 guidelines recommend post-pyloric feeding tubes and semi-recumbent positioning with a head of bed angle of greater than 45 degrees to decrease the frequency of aspiration associated with enteral feeding [1]. Unfortunately, it is difficult to maintain patients at 45 degrees, and 30 degree elevation may not be as effective [22]. Some research suggests that postponing full-calorie nutrition may be another option [23]. A 2002 single-center study evaluating initial trophic feeding followed by delayed full-calorie nutrition found a significant reduction in VAP with no change in mortality compared with the control group [23]. A multicenter trial is now under way to confirm these results [24].

\section{Maintaining natural immunity}

Stress ulcer prophylaxis with acid suppression predisposes patients to developing VAP by raising the gastric $\mathrm{pH}$ levels and allowing bacterial overgrowth [25]. Sucralfate is an appealing option because it does not affect gastric $\mathrm{pH}$, but it has been associated with increased bleeding and VAP incidence $[26,27]$. Citing conflicting evidence, the 2005 guidelines recommend using either sucralfate or $\mathrm{H} 2$ blockers for stress ulcer prophylaxis [1]. More recently, acid suppression therapy with more potent proton pump inhibitors has become widespread [25], but it was associated with a greater incidence of VAP than $\mathrm{H} 2$ blockers in a retrospective study [25]. To help maintain natural immunity, the guidelines also recommend a conservative transfusion policy and intensive insulin therapy since blood transfusion and hyperglycemia have been associated with increased infectious complications [1]. However, intensive insulin regimens have been increasingly scrutinized as new data suggesting their potential for harm emerge [28-30].

\section{Liberating patients from the ventilator}

The 2005 guidelines recommend avoiding intubation, and particularly reintubation whenever possible, as well 
as installing protocols to reduce sedation and accelerate ventilator weaning [1]. In 2008, the Awakening and Breathing Controlled trial confirmed the importance of combining sedation and ventilator weaning protocols by showing a shorter duration of mechanical ventilation and significant mortality improvement in the intervention group [31].

For patients who are unlikely to be liberated from the ventilator quickly, early tracheostomy has been used to mitigate the risks associated with endotracheal intubation, but its role is controversial. A 2004 randomized clinical trial showed a significant reduction in VAP, duration of mechanical ventilation, and mortality in patients who received tracheostomy on ventilator day 2 rather than prolonged endotracheal intubation with tracheostomy on ventilator day 14 [32]. However, follow-up studies have not replicated these findings [33,34]. A 2006 meta-analysis showed decreased ventilation duration and ICU length of stay but no difference in mortality or VAP in those treated with early tracheostomy [34]. In 2008, a small randomized trial also showed no difference between tracheostomy within the first 4 days of intubation and prolonged intubation with tracheostomy allowed only after ventilator day 14 , other than improved patient comfort, but the study was too underpowered to be conclusive [33].

\section{Implications for clinical practice}

VAP leads to excess morbidity, mortality, and costs in critically ill patients. While many prevention strategies have proven successful in decreasing the incidence of VAP by a small amount, significant reduction requires a multimodal approach encompassing positioning, equipment, nutritional support, infection control, sedation minimization, and ventilator weaning. Adjunctive therapies such as stress ulcer prophylaxis, glycemic control, and blood transfusion also play a role because of their impact on the immune system. Vigilant attention to all of these details by means of a ventilator bundle has been shown to significantly reduce the incidence of VAP $[35,36]$. Many other promising therapies, such as selective gut decontamination, early tracheostomy, and coated endotracheal tubes, remain controversial because of their mixed or limited data, so we await further trials to determine their role. VAP prevention remains an area of active research, with 28 clinical trials currently listed on www.clinicaltrials.gov.

\section{Abbreviations}

ICU, intensive care unit; VAP, ventilator-associated pneumonia.

\section{Competing interests}

The authors declare that they have no competing interests.

\section{Acknowledgements}

JMO is funded through the National Institutes of Health/ National Heart, Lung and Blood Institute (K23 HL075076).

\section{References}

I. American Thoracic Society; Infectious Diseases Society of America: Guidelines for the management of adults with hospitalacquired, ventilator-associated, and healthcare-associated pneumonia. Am J Resp Crit Care Med 2005, I 7I:388-4I6.

2. Safdar N, Crnich CJ, Maki DG: The pathogenesis of ventilatorassociated pneumonia: its relevance to developing effective strategies for prevention. Respir Care 2005, 50:725-4I.

3. Cook DJ, Walter SD, Cook RJ, Griffith LE, Guyatt GH, Leasa D, Jaeschke RZ, Brun-Buisson C: Incidence of and risk factors for ventilator-associated pneumonia for ventilator-associated pneumonia in critically ill patients. Ann Intern Med I 998, 129:430-3.

4. Kollef MH, Afessa B, Anzueto A, Veremakis C, Kerr KM, Margolis BD, Craven DE, Roberts PR, Arroliga AC, Hubmayr RD, Restrepo MI, Auger WR, Schinner R; NASCENT Investigation Group: Silvercoated endotracheal tubes and incidence of ventilatorassociated pneumonia: the NASCENT randomized trial. JAMA 2008, 300:305-I3.

FI000 Factor 6.6 Must Read

Evaluated by Roman Kozlov 26 Sep 2008, John Augoustides 26 Sep 2008, Jim O’Brien 10 Oct 2008

5. Edwards JR, Peterson KD, Andrus ML, Dudeck MA, Pollock DA, Horan TC; National Healthcare Safety Network Facilities: National Healthcare Safety Network (MHSN) Report, data summary for 2006 through 2007, issued November 2008. Am J Infect Control 2008, 36:609-26.

6. Shore AF, O'Malley PG: Continuous subglottic suctioning for the prevention of ventilator-associated pneumonia: potential economic implications. Chest 200I, I I 9:228-35.

7. Rello J, Ollendorf DA, Oster G, Vera-Llonch M, Bellm L, Redman R, Kollef MH; VAP Outcomes Scientific Advisory Group: Epidemiology and outcomes of ventilator-associated pneumonia in a large US database. Chest 2002, I 22:2 I I5-2I.

8. Muscedere J, Dodek P, Keenan S, Fowler R, Cook D, Heyland D; VAP Guidelines Committee and the Canadian Critical Care Trials Group: Comprehensive evidence-based clinical practice guidelines for ventilator-associated pneumonia: prevention. J Crit Care 2008, 23:149-52.

9. DePew $C L$, McCarthy MS: Subglottic secretion drainage. $A A C N$ Advanced Critical Care 2007, I 8:366-79.

10. D'Amico R, Pifferi S, Leonetti C, Torri V, Tinazzi A, Liberati A: Effectiveness of antibiotic prophylaxis in critically ill adult patients: systemic review of randomized controlled trials. BMJ 1998, 3 | 6: | 275-85.

II. de Smet AM, Kluytmans JA, Cooper BS, Mascini EM, Benus RF, van der Werf TS, van der Hoeven JG, Pickkers P, Bogaers-Hofman D, van der Meer NJ, Bernards AT, Kuijper EJ, Joore JC, Leverstein-van Hall MA, Bindels AJ, Jansz AR, Wesselink RM, de Jongh BM, Dennesen PJ, van Asselt GJ, te Velde LF, Frenay IH, Kaasjager K, Bosch FH, van Iterson M, Thijsen SF, Kluge GH, Pauw W, de Vries JW, Kaan JA, et al.: Decontamination of the digestive tract and oropharynx in ICU patients. N Engl J Med 2009, 360:20-3I.

FI000 Factor 6.8 Must Read

Evaluated by Direk Limmathurotsakul 02 Feb 2009, Allen Cheng 27 Feb 2009, Andrej Michalsen 06 May 2009, Lee Fleisher 21 May 2009, Jim O'Brien 21 May 2009, Francoise Dromer 06 Mar 2009

12. Cheng A: Evaluation of de Smet AM, et al:: Decontamination of the digestive tract and oropharynx in ICU patients. $N$ Engl J Med 2009, 360:20-3I. Faculty of 1000 Medicine, 27 Feb 2009. [http://www. fl000medicine.com/article/id/ I |45249].

13. Koeman M, van der Ven AJ, Hak E, Joore HC, Kaasjager K, de Smet AG, Ramsay G, Dormans TP, Aarts LP, de Bel EE, Hustinx WN, van der Tweel I, Hoepelman AM, Bonten MJ: Oral decontamination with 
chlorhexidine reduces the incidence of ventilator-associated pneumonia. Am J Resp Crit Care Med 2006, I 73:I348-55.

FI000 Factor 3.0 Recommended

Evaluated by Niall Ferguson 27 Jul 2006

14. Tantipong $\mathrm{H}$, Morkchareonpong C, Jaiyindee S, Thamlikitkul V: Randomized controlled trial and meta-analysis of oral decontamination with $2 \%$ chlorhexidine solution for prevention of ventilator associated pneumonia. Infect Control Hosp Epidemiol 2008, 29:|3|-6.

15. Chlebicki MP, Safdar N: Topical chlorhexidine for prevention of ventilator-associated pneumonia: a meta-analysis. Crit Care Med 2007, 35:595-602.

16. Scannapieco FA, Yu J, Raghavendran K, Vacanti A, Owens SI, Wood K, Mylotte JM: A randomized trial of chlorhexidine gluconate on oral bacterial pathogens in mechanically ventilated patients. Crit Care 2009, I3:RII7.

17. Bellissimo-Rodrigues F, Bellissimo-Rodrigues WT, Viana JM, Teixeira GC, Nicolini E, Auxiliadora-Martins $M$, Passos AD, Martinez EZ, Basile-Filho A, Martinez R: Effectiveness of oral rinse with chlorhexidine in preventing nosocomial respiratory tract infection among intensive care unit patients. Infect Control Hosp Epidemiol 2009, 30:952-8.

18. Panchabhai TS, Dangayach NS, Krishnan A, Kothari VM, Karnad DR: Oropharyngeal cleansing with $0.2 \%$ chlorhexidine for prevention of nosocomial pneumonia in critically ill patients: an open-label randomized trial with $0.01 \%$ potassium permanganate as control. Chest 2009, 135: I 150-6.

19. Shorr AF, Zilberberg MD, Kollef M: Cost-effectiveness analysis of a silver-coated endotracheal tube to reduce the incidence of ventilator-associated pneumonia. Infect Control Hosp Epidemiol 2009, 30:759-63.

20. Metheny NA, Clouse RE, Chang YH, Stewart BJ, Oliver DA, Kollef $\mathrm{MH}$ : Tracheobronchial aspiration of gastric contents in critically ill tube-fed patients: frequency, outcomes, and risk factors. Crit Care Med 2006, 34:I007-I5.

21. McClave SA, Martindale RG, Vanek VW, McCarthy M, Roberts $P$, Taylor B, Ochoa JB, Napolitano L, Cresci G; ASPEN Board of Directors; American College of Critical Care Medicine; Society of Critical Care Medicine: Guidelines for the Provision and Assessment of Nutrition Support Therapy in Adult Critically ILL Patient: Society of Critical Care Medicine (SCCM) and American Society for Parenteral and Enteral Nutrition (ASPEN). JPEN J Parenter Enteral Nutr 2009, 33:277-316.

22. van Nieuwenhoven $C A$, Vandenbroucke-Grauls $C$, van Tiel $F H$, Joore HC, van Schijndel RJ, van der Tweel I, Ramsay G, Bonten MJ: Feasibility and effects of the semirecimbent position to prevent ventilator-associated pneumonia: a randomized study. Crit Care Med 2006, 34:396-402.

23. Ibrahim EH, Mehringer L, Prentice D, Sherman G, Schaiff R, Fraser V, Kollef $\mathrm{MH}$ : Early versus late enteral feeding of mechanically ventilated patients: results of a clinical trial. JPEN J Parenter Enteral Nutr 2002, 26: I74-81.

24. Early Versus Delayed Enteral Feeding and Omega-3 Fatty Acid/Antioxidant Supplementation for Treating People With Acute Lung Injury or Acute Respiratory Distress Syndrome (The EDEN-Omega Study). [http://clinicaltrials.gov/ct2/show/ NCT00609180].

25. Miamo, TA, Reichert MG, Houle TT, MacGregor DA, Kincaid EH, Bowton DL: Nosocomial pneumonia risk and stress ulcer prophylaxis: a comparison of pantoprazole vs ranitidine in cardiothoracic surgery patients. Chest 2009, I36:440-7.

26. Cook D, Guyatt G, Marshall J, Leasa D, Fuller H, Hall R, Peters S, Rutledge F, Griffith L, McLellan A, Wood G, Kirby A: Canadian Critical Care Trials Group. A comparison of sucralfate and ranitidine for the prevention of upper gastrointestinal bleeding in patients requiring mechanical ventilation. $N$ Engl J Med 1998, 338:791-7.

27. Markowicz P, Wolff M, Djedaïni K, Cohen Y, Chastre J, Delclaux C, Merrer J, Herman B, Veber B, Fontaine A, Dreyfuss D: Multicenter prospective study of ventilator-associated pneumonia during acute respiratory distress syndrome. Incidence, prognosis, and risk factors. ARDS Study Group. Am J Respir Crit Care Med 2000, I | 6: |492-8.

28. Preiser JC, Devos P, Ruiz-Santana S, Mélot C, Annane D, Groeneveld J, lapichino G, Leverve X, Nitenberg G, Singer P, Wernerman J, Joannidis M, Stecher A, Chioléro R: A prospective randomised multi-centre controlled trial on tight glucose control by intensive insulin therapy in adult intensive care units: the Glucontrol study. Intensive Care Med 2009, 35:I738-48.

FI000 Factor 3.0 Recommended

Evaluated by Alain Vuylsteke 21 Oct 2009

29. Griesdale DE, de Souza RJ, van Dam RM, Heyland DK, Cook DJ, Malhotra A, Dhaliwal R, Henderson WR, Chittock DR, Finfer S, Talmor $\mathrm{D}$ : Intensive insulin therapy and mortality among critically ill patients: a meta-analysis including NICE-SUGAR study data. CMAJ 2009, I80:821-7.

30. NICE-SUGAR Study Investigators, Finfer S, Chittock DR, Su SY, Blair D, Foster D, Dhingra V, Bellomo $R$, Cook D, Dodek $P$, Henderson WR, Hébert PC, Heritier S, Heyland DK, McArthur C, McDonald E, Mitchell I, Myburgh JA, Norton R, Potter J, Robinson BG, Ronco J]: Intensive versus conventional glucose control in critically ill patients. N Engl J Med 2009, 26:1283-97.

\section{Changes Clinical Practice}

FI000 Factor 12.6 Exceptional

Evaluated by Benedikt Preckel 31 Mar 2009, Walter Hasibeder 03 Apr 2009, Jean-Charles Preiser 08 Apr 2009, Nicholas Barrett 09 Apr 2009, Nigel Webster 16 Apr 2009, Alain Vuylsteke 23 Apr 2009, Antoni Torres 29 Apr 2009, Greg Martin 29 Apr 2009, Marc De Kock 30 Apr 2009, John Laffey 0I May 2009, Babak Sarani 22 May 2009, Seth Field 29 May 2009, Bruce Bistrian 05 Jun 2009, John Augoustides 24 Jul 2009, Manfred Seeberger II Aug 2009

31. Girard TD, Kress JP, Fuchs BD, Thomason JW, Schweickert WD, Pun BT, Taichman DB, Dunn JG, Pohlman AS, Kinniry PA, Jackson JC, Canonico AE, Light RW, Shintani AK, Thompson JL, Gordon SM, Hall JB, Dittus RS, Bernard GR, Ely EW: Efficacy and safety of a paired sedation and ventilator weaning protocol for mechanically ventilated patients in intensive care (Awakening and Breathing Controlled trial): a randomized controlled trial. Lancet 2008, 371:126-34.

Changes Clinical Practice

FI000 Factor 10.0 Exceptional

Evaluated by Ognjen Gajic 21 Jan 2008, Christer Sinderby 06 Feb 2008, Paolo Navalesi OI Apr 2008, Jim O’Brien 17 Apr 2008, Marjolein de Wit 06 May 2008

32. Rumbak MJ, Newton M, Truncale T, Schwartz SW, Adams JW, Hazard PB: A prospective, randomized, study comparing early percutaneous dilational tracheotomy to prolonged translaryngeal intubation (delayed tracheotomy) in critically ill medical patients. Crit Care Med 2004, 32:1689-94.

33. Blot F, Similowski T, Trouillet JL, Chardon P, Korach JM, Costa MA, Journois D, Thiéry G, Fartoukh M, Pipien I, Bruder N, Orlikowski D, Tankere F, Durand-Zaleski I, Auboyer C, Nitenberg G, Holzapfel L, Tenaillon A, Chastre J, Laplanche A: Early Tracheostomy versus prolonged endotracheal intubation in unselected severely ill ICU patients. Intensive Care Med 2008, 34:I779-87.

34. Griffiths J, Barber VS, Morgan L, Young JD: Systemic review and meta-analysis of studies of the timing of tracheostomy in adult patients undergoing artificial ventilation. BMJ 2005, 330:I 243.

35. Blamoun J, Alfakir M, Rella ME, Wojcik JM, Solis RA, Anees Khan M, DeBari VA: Efficacy of an expanded ventilator bundle for reduction of ventilator-associated pneumonia in the medical intensive care unit. Am J Infect Control 2009, 37:I72-5.

36. Hutchinsons K, Karras G, Erwin J, Sullivan KL: Ventilatorassociated pneumonia and oral care: a successful quality improvement project. Am J Infect Control 2009, 37:590-7. 